\title{
Incidence of Retained Placenta in Relation with Breed, Age, Parity and Body Condition Score of Dairy cows
}

\author{
Islam MH*, Sarder MJU, Rahman M, Kader MA and Islam MA \\ Department of Animal Husbandry \& Veterinary Science, Faculty of Agriculture, University of Rajshahi, \\ Bangladesh.
}

[Received: February 7, Accepted: March 29, 2012]

\begin{abstract}
Retained placenta is an economically important reproductive disorder which occurs at the end of the reproductive cycle and has repercussions on the next. The study was conducted a total 1205 dairy cows from 9 upazila and 4 Metro Thana of Rajshahi during the period from July 2010 to June 2011. To evaluate the incidence of retained placenta in relation to breed, age, parity and body condition score of dairy cows. A questionnaire was prepared including information viz. name and address of farmer, breed, age; parity and body condition score for achievement of the study. The overall prevalence of retained placenta was $13.4 \%$. The influencing factors including breed, age, parity, body condition score had significant effect $(\mathrm{P}<0.05)$ on retained placenta. The highest prevalence was $10.7 \%, 4.5 \%, 5.6 \%$ and $7.1 \%$ observed in cross-breed, $>3$ years age, $1^{\text {st }}$ parity and fair body condition group of cows, respectively. From this study, it might be concluded that local breed, $\geq 3$ years but less than 5 years age group, $3^{\text {rd }}$ parity had least risk for retained placenta.
\end{abstract}

Key words: Incidence, retained placenta, age, parity, body condition and dairy cows.

\section{INTRODUCTION}

Livestock is an integral part of agriculture in our country. Cattle are the important species of livestock in Bangladesh. Cattle is an important factor in agricultural operation which provides valuable food of animal origin like milk, meat, milk products; industrial raw materials like skin and manures. Diseases of dairy cattle substantially limit production performances. Among the reproductive diseases retained placenta is an important reproductive cyclical problem that has repercussions on the next calving ${ }^{[1]}$. A retained placenta usually causes the cow to delay the next pregnancy for 2-6 months, late calving date in the following year and may result in an open cow next year ${ }^{[2]}$. A six-month delay may result in an open cow next year at pregnancy checking time. The tetanus, an important complication of retained placenta, caused by Clostridium tetani which can be found in the soil or in the feces and gets into the uterus where it set up an infection resulting lockjaw ${ }^{[3]}$. In dairy cows, retained placenta may be the cause of serious economic losses in the herd due to decreased milk production, illness and treatment cost, beside a decreased market value of the animal ${ }^{[4,5]}$. There are many factors influencing the incidence of retained fetal membranes like abortion, dystocia, multiple birth, poor body condition score, age, nutritional deficiencies, hormonal imbalance [6, 7]. Aged cows showed a higher incidence ${ }^{[8]}$ of retained fetal membrane than $4,5,6,7$ years old ${ }^{[9]}$. The number of calving was negatively correlated with the incidence of retained fetal membrane. A higher incidence $(44.7 \%)$ affected the heifers and their calving while it was $10-13 \%$ after second and third calving, 10-21\% after fourth and fifth ones ${ }^{[10]}$. There is no available data on retained placenta in dairy cows at Rajshahi district. The present study has been taken to evaluate the prevalence of retained placenta in dairy cows on different factors at Rajshahi district in Bangladesh.

\section{MATERIALS AND METHODS}

The study area and data collection: The study was conducted a total 1205 calvings from 1205 dairy cows from 9 upazila and 4 Metro Thana of Rajshahi. The name of 9 upazilas were viz., Poba, Godagari, Tanor, Mohonpur, Bagmara, Puthia, Durgapur, Bagha and Charghat and 4 Metro Thanas namely Boalia, Rajpara, Motihar and Shamukhdum at Rajshahi district in Bangladesh during the period from July 2010 to June 2011. A structural questionnaire prepared for collecting the information and estimates the incidence of retained placenta in relation with age, parity and body weight and body condition of dairy cows. The data collected directly from owner of dairy farms and register books of government and private farms.

Management of cows: In experimental, the individual cow owners were housed their cows were traditional housing and most of them feeding straw and green grass, few concentrate feeding and little feeding balanced diet; very few were deworming and vaccinating their cows and most of the farmer were not waiting more than twelve hours for placental come out, after one to two hours they called doctors for manually removed. But mini and large sized 
dairy farmer had improved practiced on rearing, feeding, deworming and vaccination. When the cows prior to calved most of our farmer fed their animals worm rice gruel and separated from others animal with paddy straw bedding were used.

Table 1: The Incidence of retained placenta among cross and indigenous dairy cows. health condition the lumber vertebral processes of the cows were used as landmark. The body condition of the cows were divided into three classes such as- Group 1: Poor $(n=181)$, Group 2: Fair $(n=746)$ and Group 3: Good $(\mathrm{n}=278)$

\begin{tabular}{|c|c|c|c|c|c|}
\hline \multirow{2}{*}{$\begin{array}{l}\text { Placental } \\
\text { condition }\end{array}$} & \multicolumn{2}{|c|}{ Breed Type } & \multirow{2}{*}{ Total } & \multirow{2}{*}{$\begin{array}{l}\text { Chi- Square }\left(\chi^{2}\right) \\
\text { Calculated value } \\
(\mathrm{P}<0.05)\end{array}$} & \multirow{2}{*}{$\begin{array}{l}\text { Chi- Square }\left(\chi^{2}\right) \\
\text { tabulated value }\end{array}$} \\
\hline & Local & Cross-bred & & & \\
\hline \multirow{2}{*}{ Retained } & 33 & 129 & 162 & \multirow{6}{*}{$27.315^{*}$} & \multirow{6}{*}{3.841} \\
\hline & $(2.7 \%)$ & $10.7 \%)$ & $(13.4 \%)$ & & \\
\hline Normally & 437 & 606 & 1043 & & \\
\hline Expelled & $(36.3 \%)$ & $(50.3 \%)$ & $(86.6 \%)$ & & \\
\hline \multirow{2}{*}{ Total } & 470 & 735 & 1205 & & \\
\hline & $(39.0 \%)$ & $(61.0 \%)$ & $(100 \%)$ & & \\
\hline
\end{tabular}

Grouping of Experimental Cows: To achieve the goal animals were group according to following considering factors:

Breed- The cows was classified in Indigenous or Local $(n=470)$ and Crossbred $(n=735)$.

Age- The age cows were determined from birth register and examined by teeth and cornual ring reading. After confirmation of age of these cows and then classified as follows- Group I: $<3$ years $(\mathrm{n}=295)$, Group II: 3 - <5 years $(\mathrm{n}=430)$, Group III: 5 - <7 years $(\mathrm{n}=291)$ and Group IV: > 7 years $(\mathrm{n}=189)$.

Parity- The cows those gave $1^{\text {st }}$ calf considered as parity $1\left(\mathrm{P}_{1}\right)$, those gave $2^{\text {nd }}$ calf consider as parity 2 $\left(\mathrm{P}_{2}\right), 3^{\text {rd }}$ calf as parity $3\left(\mathrm{P}_{3}\right)$ and so on.

Table 2: Effect of age on Incidence of retained placenta of dairy cows

Body Condition Score (BCS) - In order to record the
Where, Poor = Marked emaciated.
Fair = Ribs are usually visible, little fat
covered dorsal spines are barely visible.

Good = Animals are smooth and well covered but fat deposits are not marked.

\section{Statistical analysis:}

The data were compiled; SPSS program ${ }^{[11]}$ to analyze the incidence and chi-square method used for interpretation of the findings. Retention of placenta (retained placenta, fetal membrane or afterbirth) was defined in this study as failure of spontaneous expulsion of the placenta within 12 hours after parturition.

\section{RESULTS AND DISCUSSION}

The overall incidence of retained placenta was $13.4 \%$ which was closer to various researchers and their incidence were $12.6 \%{ }^{[12]}, 10.0 \%{ }^{[13]}$ and $8.8 \%{ }^{[14]}$ but differ from results were $7.0 \%{ }^{[6]}, 1.96 \%{ }^{[15]}$ and $7.1 \%$ ${ }^{[16]}$ respectively.

\begin{tabular}{|c|c|c|c|c|c|c|c|}
\hline \multirow{2}{*}{$\begin{array}{l}\text { Placental } \\
\text { condition }\end{array}$} & \multicolumn{4}{|c|}{ Age group } & \multirow{2}{*}{ Total } & \multirow{2}{*}{$\begin{array}{lr}\text { Chi- } & \text { Square } \\
\left(\chi^{2}\right) & \text { Calculated } \\
\text { value } & (P<0.05) .\end{array}$} & \multirow{2}{*}{$\begin{array}{l}\text { Chi- Square } \\
\left(\chi^{2}\right) \\
\text { tabulated } \\
\text { value }\end{array}$} \\
\hline & $<3$ years & $\begin{array}{c}3 \text { years to } \\
<5 \text { years }\end{array}$ & $\begin{array}{l}5 \text { to }< \\
7 \text { years }\end{array}$ & $>7$ years & & & \\
\hline \multirow[t]{2}{*}{ Retained } & 54 & 35 & 37 & 36 & 162 & \multirow{6}{*}{$21.621^{*}$} & \multirow{6}{*}{7.815} \\
\hline & $(4.5 \%)$ & $(2.9 \%)$ & $(3.1 \%)$ & $(3.0 \%)$ & $(13.4 \%)$ & & \\
\hline Normally & 241 & 395 & 254 & 153 & 1043 & & \\
\hline Expelled & $(20.0 \%)$ & $(32.8 \%)$ & $(21.1 \%)$ & $(12.7 \%)$ & $(86.6 \%)$ & & \\
\hline \multirow[t]{2}{*}{ Total } & 295 & 430 & 291 & 189 & 1205 & & \\
\hline & $(24.5 \%)$ & $(35.7 \%)$ & $(24.1 \%)$ & $(15.7 \%)$ & $(100 \%)$ & & \\
\hline
\end{tabular}


Table 3: The effects of parity on the Incidence of retained placenta of dairy cows lowest incidence were in exotic and indigenous breed. Age had significance effects $(P<0.05)$ on

\begin{tabular}{|c|c|c|c|c|c|c|c|c|c|}
\hline \multirow{2}{*}{$\begin{array}{l}\text { Placental } \\
\text { condition }\end{array}$} & Parity & & & & & & \multirow{2}{*}{ Total } & \multirow{2}{*}{\multicolumn{2}{|c|}{$\begin{array}{ll}\text { Chi- } \quad \text { Square } & \text { Chi- } \\
\left(\chi^{2}\right) & \text { Square }\left(\chi^{2}\right) \\
\text { Calculated } & \text { tabulated } \\
\text { value } & \text { value } \\
(P<0.05) . & \end{array}$}} \\
\hline & $\mathrm{P}_{1}$ & $\mathrm{P}_{2}$ & $\mathrm{P}_{3}$ & $\mathrm{P}_{4}$ & $\mathrm{P}_{5}$ & $\mathrm{P}_{6}$ & & & \\
\hline \multirow{2}{*}{ Retained } & 68 & 23 & 12 & 26 & 9 & 24 & 162 & \multirow{6}{*}{$27.323 *$} & \multirow{6}{*}{11.070} \\
\hline & $(5.6 \%)$ & $(1.9 \%)$ & $(1.0 \%)$ & $(2.2 \%$ & $0.7 \%$ & $2.0 \%$ & $(13.4 \%)$ & & \\
\hline \multirow{2}{*}{$\begin{array}{l}\text { Normally } \\
\text { Expelled }\end{array}$} & 368 & 256 & 159 & 132 & 58 & 70 & 1043 & & \\
\hline & \multicolumn{7}{|c|}{$(30.5 \%)(21.2 \%)(13.2 \%)(11.0 \%)(4.8 \%)(5.8 \%)(86.6 \%)$} & & \\
\hline \multirow{2}{*}{ Total } & 436 & 279 & 171 & 158 & 67 & 94 & 1205 & & \\
\hline & \multicolumn{7}{|c|}{$(36.2 \%)(23.2 \%)(14.2 \%)(13.2 \%)(5.6 \%)(7.8 \%)(100.0 \%)$} & & \\
\hline
\end{tabular}

The low incidence of retention of placenta could be due to the area, breed and indiscrimination of data collection ${ }^{[17]}$, hormonal imbalance ${ }^{[6]}$, nutrition ${ }^{[18,19]}$ and genital infection ${ }^{[20,21]}$. The influencing factors including breed, age,

parity and body condition score on investigation of retained placenta.

Breed had direct influence on retained placenta. Crossbred had higher $(10.5 \%)$ incidence than indigenous $(2.7 \%)$ one and significant effect $(P<0.05)$. Azad ${ }^{[22]}$ reported retained placenta in cross and local breed were $37.5 \%$ \& $25.0 \%$, incidence of retained placenta of dairy cows. The incidence of retained placenta of dairy cows at Rajshahi was in $<3$ yrs, 3 yrs to $<5 y$ yrs, 5 to $<7$ yrs and $>7$ yrs were $4.5 \%, 2.9 \%, 3.1 \%$ and $3.0 \%$, respectively. Sarder et.al. ${ }^{[14]}$ observed $4.4 \%, 10.4 \%$, $8.7 \%$ and $5.5 \%$ the incidence of retained placenta were in 4 years, 4 to 6 years, 6 to 8 years, respectively. Ali ${ }^{[9]}$ stated retained placenta with age of cows in <4yrs, 4-<7yrs, 7-<10 yrs and 10yrs were $9.4 \%, 19.2,38.1 \%$ and $51.9 \%$, respectively. Azad ${ }^{[22]}$ also obtained rate of retained placenta in 3-5 yrs and $5 y r$ of age group of cows were $33.3 \%$ and $37.5 \%$. The older aged ( $>7$ years) of cows had the highest $(4.5 \%)$ incidence of retained placenta than young $(3$

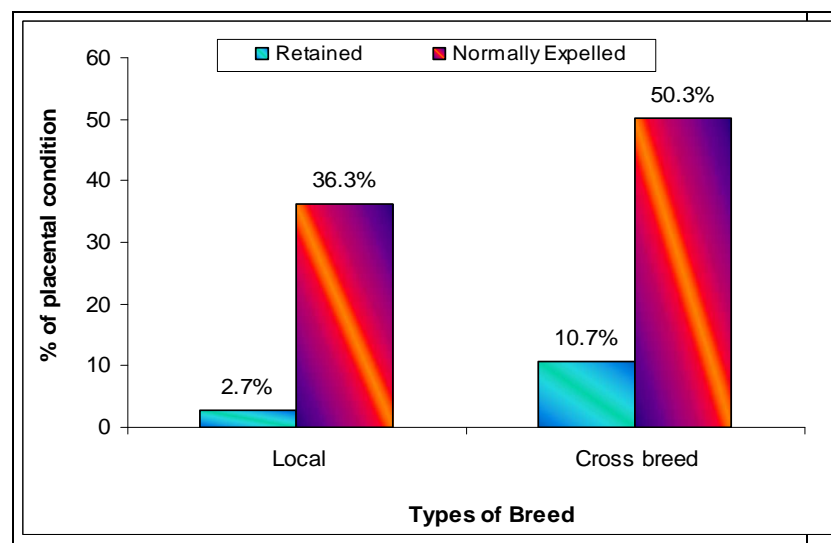

Figure 1: Graphical representation of percentages of retained placenta in relation with breed of cows.

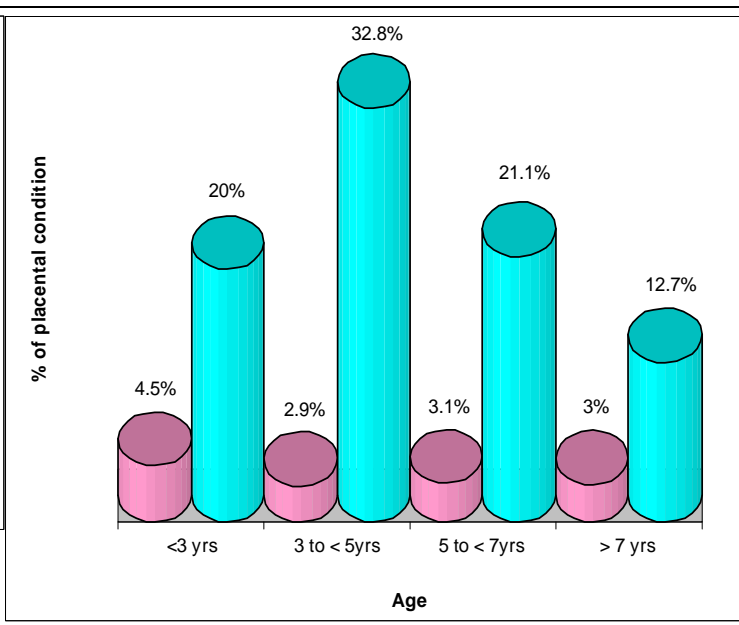

Figure 2: Cylinder bar diagram indicates the proportion of placental condition and age group of cows. respectively but similar findings $\left[\begin{array}{llll}9, & 21, & 23\end{array}\right]$ that influences of retained placenta and the highest and to 5 years) age and 5 to 7 years of age similar result showed by various authors $[8,9,14,16,22,24]$ and 
partially agreed with ${ }^{[25,26]}$ but they differ in heifer (> 3 years) group.

Table 4: The effects of body condition score on the Incidence of retained placenta of dairy cows and $37.5 \%$ for treatment and control group, respectively; Sarder ${ }^{[8]}$ showed that retained placenta occurred significantly higher in cows over $6^{\text {th }}$ parity than $3^{\text {rd }}$ parity. Stevenson and Call ${ }^{[28]}$ reported that retained placenta increases with advancing parity except in heifer. Similarly Saloniemi et. al. ${ }^{[29]}$ showed that the incidence of

\begin{tabular}{|c|c|c|c|c|c|c|}
\hline \multirow{2}{*}{$\begin{array}{l}\text { Placental } \\
\text { condition }\end{array}$} & \multicolumn{3}{|c|}{ Body Condition Score } & \multirow[b]{2}{*}{ Total } & \multirow{2}{*}{$\begin{array}{l}\text { Chi- Square }\left(\chi^{2}\right) \\
\text { Calculated value } \\
(P<0.05) .\end{array}$} & \multirow{2}{*}{$\begin{array}{l}\text { Chi- Square }\left(\chi^{2}\right) \\
\text { tabulated value }\end{array}$} \\
\hline & Poor & Fair & Good & & & \\
\hline Retained & $\begin{array}{l}37 \\
(3.1 \%)\end{array}$ & $\begin{array}{l}86 \\
(7.1 \%)\end{array}$ & $\begin{array}{l}39 \\
(3.2 \%)\end{array}$ & $\begin{array}{l}162 \\
(13.4 \%)\end{array}$ & \multirow{3}{*}{$10.052 *$} & \multirow{3}{*}{5.991} \\
\hline $\begin{array}{l}\text { Normally } \\
\text { Expelled }\end{array}$ & $\begin{array}{l}144 \\
(12.0 \%)\end{array}$ & $\begin{array}{l}660 \\
(54.8 \%)\end{array}$ & $\begin{array}{l}239 \\
(19.8 \%)\end{array}$ & $\begin{array}{l}1043 \\
(86.6 \%)\end{array}$ & & \\
\hline Total & $\begin{array}{l}181 \\
(15.0 \%)\end{array}$ & $\begin{array}{l}746 \\
(61.9 \%)\end{array}$ & $\begin{array}{l}278 \\
(23.1 \%)\end{array}$ & $\begin{array}{l}1205 \\
(100 \%)\end{array}$ & & \\
\hline
\end{tabular}

* Significant at $5 \%$ level; $\mathrm{P}_{1}=1^{\text {st }}$ calving, $\mathrm{P}_{2}=2^{\text {nd }}$ calving, $\mathrm{P}_{3}=3^{\text {rd }}$ calving, $\mathrm{P}_{4}=4^{\text {th }}$ calving, $\mathrm{P}_{5}=5^{\text {th }}$ calving $\& \mathrm{P}_{6}=>6$ th calving.

The parity had significant effect $(P<0.05)$ on incidence of retained placenta of dairy cows. The highest occurrence of retained placenta was recorded $5.2 \%$ in first parity and decreasing $2.2 \%$ in $4^{\text {th }}$ parity, 2.0 in $6^{\text {th }}$ parity $\%, 1.9 \%$ in $2^{\text {nd }}$ parity, $1.0 \%$ in $3^{\text {rd }}$ parity and $0.7 \% 5^{\text {th }}$ parity. Most of researcher showed similar results. Sarder et. al. ${ }^{[14]}$ showed the incidence of retained placenta at $1^{\text {st }}$ parity, $2^{\text {nd }}$ parity, $3^{\text {rd }}$ parity, $4^{\text {th }}$ parity, $5^{\text {th }}$ parity and $>6^{\text {th }}$ parity ware $8.5 \%, 13.3 \%, 6.1 \%, 9.4 \%, 20 \%$ and $28.7 \%$, respectively which is closer to this study. Gaafar et. $a l .{ }^{[27]}$ reported the incidence of retained placenta in Friesian cows increased significantly $(\mathrm{P}<0.05)$ from $14.20 \%$ for 1 st parity to $54.60 \%$ for 8 th parity. Azad ${ }^{[22]}$ reported the rates of retention of placenta was in $1^{\text {st }}-2^{\text {nd }}$ and $3^{\text {rd }}-5^{\text {th }}$ parity were $15.0 \%, 15 \%, 33.3 \%$ retention of foetal membranes, metritis and dystocia was lowest in second party except $1^{\text {st }}$ parity. From the owners' statement about $1^{\text {st }}$ parity, it was known that the majority of the animals had had their premature delivery and history of the remaining animals was unknown. Grunert ${ }^{[6]}$ stated that most of the cases placental retention was occurred by disturbance of the loosening mechanism in the placentomes.

Body condition had significant effect $(\mathrm{P}<0.05)$ on incidence of retained afterbirth of dairy cows. The present study showed $7.1 \%, 3.2 \%$ and $3.1 \%$ of incidence of retained placenta in fair, good and poor condition of cows. Whereas Sarder et. al. [14] reported that the prevalence of retained placenta was higher in good condition, lower in fair and other in poor condition cows, respectively. These differences may be due to several risk factors such as uterine contractility, last calving type, body condition during

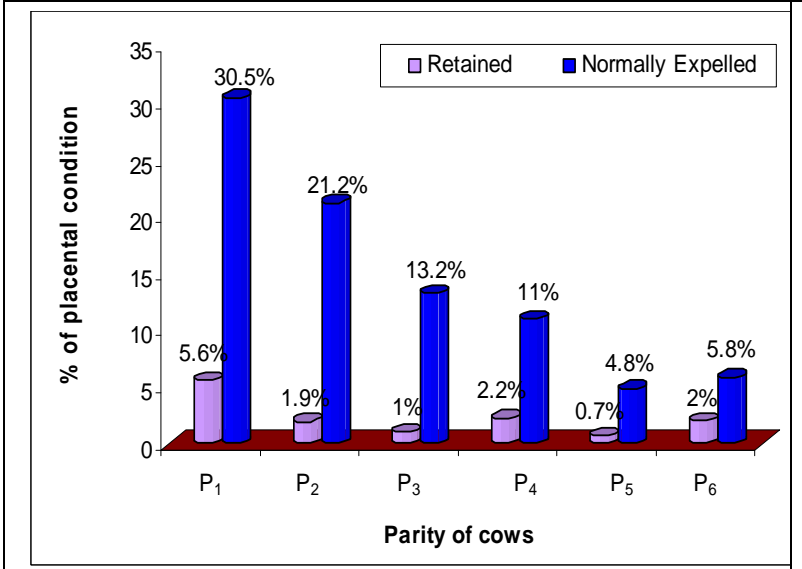

Figure 3: Bar diagram demonstrate the percentages of placental relation with parity of cows

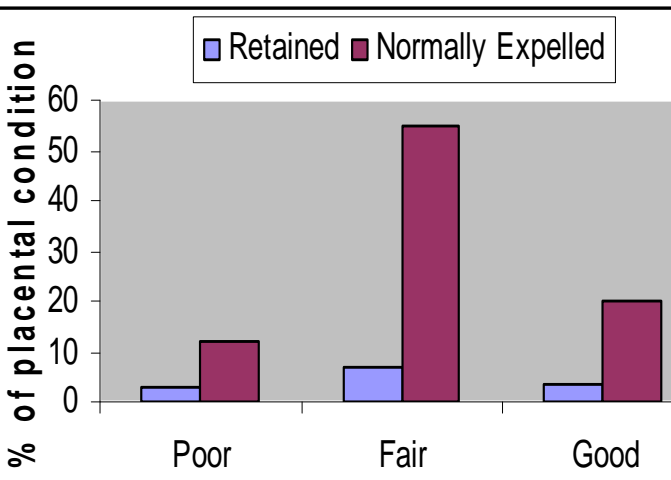

Body condition score of cows

Figure 4: Bar diagram demonstrate the percentages of placental relation with BCS group of cows. 
pregnancy, the time of onset of post partum oestrus, still birth, birth of twin, month and season of calving ${ }^{[17]}$, hereditary ${ }^{[30,31]}$, gestation length ${ }^{[6]}$, dietary deficiencies of carotene, vitamin $\mathrm{A}^{[19]}$, progesterone and oestrogen imbalance at parturition ${ }^{[6]}$, difficult delivery, age and parity of the cows ${ }^{[30]}$ and other uterine infections, which predispose the cows to retention of after birth.

\section{CONCLUSION}

The local breed, 3 to 5 years age group, $2^{\text {nd }}$ and $3^{\text {rd }}$ parity, good body condition score had less chance of retention of placenta in dairy cows at Rajshahi district in Bangladesh.

\section{REFERENCES}

1. Joosten I, Stelwagen I and Dijkhuizen FA (1988). Economic and Reproductive consequences of retained placenta in dairy cattle. The Veterinary Record 123: 53-57.

2. Borel N, Thoma R, Spaeni P, Weilenmann R, TeanKum K and Brugnera E (2006). Chlamydiarelated abortion in cattle from Graubunden. Switzerland Veterinary Pathology 43:702-708.

3. John Maas (2008). Treating and Preventing Retained Placenta in Beef Cattle UCD Veterinary Views, California Cattlemen's Magazine.

4. Ahmed WM, El-Ekhnawy KI, Desouky HM, Zaabal MM and Ahmed YF (1999). Investigations on retained fetal membranes in Friesian cows in Egypt. Egyptian Journal of Comparative Pathology and Clinical Pathology 12: 160-177.

5. Semacan A and Servinc M (2005). Liver function in cows with retained placenta. Turkish Journal of Veterinary and Animal Sciences 29: 775-778.

6. Grunert E (1986). Etiology and pathogenesis of bovine retained placenta. In: Current Therapy in Theriogenology. Edt. Morrow DA. $2^{\text {nd }}$ ed. $W_{13}$ Saunders Co. Philadelphia, London. pp. 237-242.

7. Alam MGS and Dobson H (1986). Postpartum release of Prostaglandins $\mathrm{F}_{2}$ alpha $\left(\mathrm{PGF}_{2} \alpha\right)$ and the effect of oestradiol benzoate on the concentration of $\mathrm{PGF}_{2} \alpha$ metabolite in postpartum and normal cyclic cows. Bangladesh Veterinary Journal 20: 73-81.

8. Sarder MJU (2008). Occurrence of reproductive disorders in crossbred cows of Northern Bangladesh. $15^{\text {th }}$ International Congress on Biotechnology in Animal Reproduction, Bangladesh Agricultural University, Mymensingh p. 74

9. Ali ML (1997). Retrospective epidemiologic study of periparturient diseases in dairy cows. 3 .
Retention of placenta. The Bangladesh Veterinarian 14(1-2): 53-57.

10. Majeed AF, Aboud QM, Hassan MS and Muhammad AY (2009). Retained fetal membranes in Friesian-Hoistein cows and effect of some treatment methods. Iraqi Journal of Veterinary Sciences 23: 5-8.

11.SPSS/PC, Windows for version-10.0. Release on 27.10.199 (Microsoft Corp). Trends. SPSS Inc., Michigan Avenue. Chicago. IL.pp:19-182.

12.Rahman MF, Hossain MS and Prodhan MAM (1993). Reproductive problems of cattle in Bangladesh. The Bangladesh Veterinarian 10: 71-73.

13. Francos G (1974). Observation on the frequency of reproductive disorders in dairy herds in Israel. Deutsche Tieraziliche Wochenschrift 81: 135-138.

14. Sarder MJU, Moni MIZ and Aktar S (2010). Prevalence of reproductive disorders of crossbred cows in the Rajshahi district of Bangladesh. SAARC Journal of Agriculture 8(2): 65-75.

15. Moller K, Newling PF, Robson HJ, Jansen GS, Meurbinge JA and Copper MG (1967). Retained placental membrane in dairy herds in the Huntly district. New Zealand Veterinary Journal 15: 111116.

16. Kaikini AS, Chikalikar GK and Dindorkar CV (1983). Reproductive disorders in Holstein $\times$ Gir $\mathrm{F}_{1}$ crossbred cows. Indian Journal of Animal Science 53(5): 556-558.

17. Shamsuddin M, Alam MGS and Ahmed JU (1988). Reproductive disorders of crossbred cows. Bangladesh Veterinary Journal 22: 21-28.

18. Romaniuk J (1978). Fertility indices in dairy cow's retained placenta. Bulletin of the Veterinary Institute, Pulawy, Poland 22: 54-59.

19. Ishak MA, Larson LL, Owen FG, Lowry SR and Erickson ED (1983). Effect of selenium, vitamins and ration on placental retention and performance of dairy cattle. Journal of Dairy Science 66: 99106.

20. Muller LD and Owens MJ (1974). Factors associated with the incidence of retained placenta. Journal of Dairy Science 57: 721-728.

21. Arthur GH, Noakes DE and Pearson H (1989). Retention of fetal membrane. in: Veterinary Reproduction and Obstetrics. 5th ed. Bailliere Tindall, London pp. 24 1-252.

22. Azad MA (2010). Prevention of retained placenta by injecting various drugs immediately after parturition in cows. MS Thesis, Department of Surgery and Obstetrics, Faculty of Veterinary Science, Bangladesh Agricultural University, Mymensingh. pp.1-48.

23. Samad MA, Rahman MH and Islam TS (1989). Factors associated with placental retention in 
Savar dairy cattle. Indian Journal of Dairy Science 42: 720-723.

24. Pandit RK, Shukla SP and Parekh HK (1981). Incidence of retained placenta in Gir cows and their crosses with special references to subsequent fertility. Indian Journal of Animal Sciences 51: 505507.

25. Curds CR, Erb HN, Sniffen CJ, Smith RD and Kronfeld DS (1985). Path analysis of dry period nutrition, postpartum metabolic and reproductive disorders, and mastitis in Holstein cows. Journal of Dairy Science 68(9): 2347-2360.

26. Erb HN and Martin SW (1980). Interrelationships between production and reproductive diseases in Holstein cows: Age and seasonal patterns. Journal of Dairy Science 63(11): 1918-1924.

27. Gaafar HMA, Shamiah ShMA, Shitta A and Ganah HAB (2010). Factors affecting retention of placenta and its influence on postpartum reproductive performance and milk production in Friesian cows. Slovak Journal of animal science 4(1): 6 - 12.
28. Stevenson JS and Call EP (1988). Reproductive disorders in the parturient dairy cow. Journal of Dairy Science 71: 2572-2583.

29. Saloniemi H, Grohn Y and Syvajarvi J (1986). An epidemiological and genetic study on registered diseases in Finnish Ayrshire cattle. It Reproductive disorders. Acta Veterinary Scandinevia 27: 196-208. (Cited: Animal Breeding Abstracts 55: 2020).

30. Dryendahl L, Mattson J and Peherson B (1977). Retained Placenta in cattle incidence, clinical data and effects on fertility. Journal of the American Veterinary Medical Association 24: 529-541.

31. Fonseca FA, Britt JH, McDaniel BT, Wilk JC and Rakes AH (1983). Reproductive traits of Holsteins and Jerseys. In: Effects of age, milk yield, and clinical abnormalities on involution of cervix and uterus, ovulation, estrous cycles, detection of estrus, conception rate, and days open. Journal of Dairy Science 66: 1128-1147. 